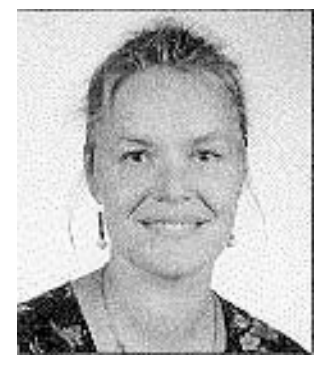

Tuija Valkeavaara

\title{
Henkilöstön kehittäjät muuttuvassa työelämässä: \\ Kehittäjien roolien ja pätevyyden arviointia Euroopan eri maissa
}

Henkilöstön kehittäminen eri muodoissaan on entistä merkittävämpi osa työorganisaatioiden toimintaa. Sen merkityksen oletetaan vain lisääntyvän. Aikuiskoulutuksen näkökulmasta henkilöstön kehittäjän työ on samalla laajeneva osa aikuiskoulutuskäytäntöä. Kehittäjien asiantuntijuus voi merkittävällä tavalla olla yhteydessä henkilöstön kehittämisen vaikuttavuuteen työorganisaatioissa.

Twenten yliopistossa Hollannissa käynnistettiin vuonna 1992 eurooppalaisten henkilöstön kehittäjien työtä ja työn edellyttämää pätevyyttä arvioiva vertailututkimus, joka toteutettiin 1992-1996 seitsemässä Euroopan maassa. Suomi integroitui hankkeeseen vuonna 1995, jolloin täällä kerättiin vastaava aineisto kuin muissa maissa. Makohtaisesti kyselyjen tuloksia on tarkemmin raportoitu toisaalla (de Rijk, Mulder \& Nijhof 1994; van Ginkel, Mulder \& Nijhof 1994a ja 1994b; Odenthal \& Nijhof 1996; Valkeavaara 1997; Vaherva \& Valkeavaara 1997). Tässä artikkelissa keskitytään vertailemaan Englannin, Italian, Hollannin, Saksan ja Suomen henkilöstön kehittäjien arvioita omista työrooleistaan, työnsä tuotoksista ja työssä tarvittavasta pätevyydestä.
Tutkimuksen taustalla on kuluvan vuosikymmenen jatkunut yhteiskunnallinen murros, joka on johtanut työn ja työorganisaatioiden sisäisten ja ulkoisten toimintaympäristöjen muuttumiseen ja uudelleen arviointiin sekä kansallisella että kansainvälisellä tasolla. Tässä murroksessa sekä organisaatioita johtavien että niissä työskentelevien ihmisten osaamisen ja jatkuvan oppimisen tukeminen on vähitellen alettu tunnustaa kestäväksi investoinniksi. Yhteiskuntapoliittisella tasolla tämä näkyy mm. EU:n julkilausumana pyrkimyksenä oppivaan yhteiskuntaan ja elinikäiseen oppimiseen. Samoin organisaation strategian ja henkilöstön kehittämisstrategian vuorovaikutussuhteen tärkeys jatkuvan oppimisen mahdollistamiseksi on korostunut. Erityisesti 1970- ja 1980-luvuille tyy- 
pillinen formaali henkilöstökoulutus on väistymässä ja painopiste on kuluvana vuosikymmenenä siirtynyt laaja-alaiseen, organisaation ja yksilön tavoitteet integroivaan työssä oppimiseen (Marsick 1988; Chalofsky 1992). Tästä on osoituksena esimerkiksi oppivien tai oppimista tukevien organisaatioiden tavoittelu ja konstruktivistisen oppimisen korostaminen aikuiskoulutuksessa.

Henkilöstön kehittämisen tavoitteiden muuttuessa on alettu myös kiinnittää huomiota organisaatioiden henkilöstön kehittämisen suunnittelusta, toteutuksesta ja/tai arvioinnista vastaavien asiantuntijoiden, henkilöstön kehittäjien työhön ja pätevyyteen (ks. esim. Eurotechnet 1995). Henkilöstön kehittäjien työtä ja pätevyysalueita on tutkittu pääosin USA:ssa (ks. esim. Pinto \& Walker 1978; McLagan \& Bedrick 1983; McLagan 1989; Nadler \& Nadler 1991), mutta myös eri Euroopan maissa (ks. esim. Launos \& Peisa 1979; Arnold \& Muller 1992). Näiden tutkimusten mukaan keskeisimmät ulottuvuudet henkilöstön kehittäjän työssä ovat olleet henkilöstökoulutuksen suunnittelu, organisointi ja toteutus, koulutus- ja kehittämistoiminnan tai -yksikön johtaminen organisaatiossa sekä organisaation tai yksilöiden urakehitystä tukeva konsultointi.

Aikuiskoulutuksen näkökulmasta henkilöstön kehittäjät nähdään usein yhtenä erityisryhmänä työelämän aikuiskouluttajia. Heitä voidaan pitää asiantuntijoina, joiden professionaalinen identiteetti ja asiantuntijuus harvemmin rakentuu yhteisen peruskoulutuksen, yhden yhteisen tieteellisen tietoperustan tai yhtenäisten työtehtävien tai tehtävänimikkeiden pohjalle. Lähinnä on kyse monialaisesta asiantuntijuudesta, jota määrittävät koulutuksen ja oppimisen sekä taloustieteen ja hallinnon tieteenalat ja vaihteleva kokemus aikuiskoulutuksesta. Hansenin, Kahnweilerin ja Wilenskyn (1994) mukaan henkilöstön kehittäjien voidaan kuitenkin sanoa muodostavan yhtenäisen ammatillisen kulttuurin, joka perustuu tietoon, kokemuksiin ja käsityksiin oppimisen ja koulutuksen vaikuttavuudesta yksilöiden ja organisaatioiden muutoksessa.
Henkilöstön kehittäjiä tutkittaessa on kyse merkittävästä joukosta työelämän vaikuttajia. Esimerkiksi henkilöstövoimavarojen johtamista eri Euroopan maissa vuosina 1990-92 kartoittaneen tutkimuksen (Larsen 1994) mukaan Saksassa (länsi), Suomessa ja Hollannissa noin 40 prosenttia yrityksistä käytti vuosittain henkilöstökoulutukseen enemmän kuin kaksi prosenttia palkkamenoista. Mainituissa maissa yli puolessa yrityksistä johtajat osallistuivat koulutukseen 3-10 päivää vuodessa. Lisäksi tutkimus osoitti, että linjajohdon vastuu henkilöstön kehittämisestä ja koulutuksesta oli lisääntynyt ja sen arvioitiin kasvavan edelleen. Tämän perusteella voidaan henkilöstön kehittäjän työn olettaa vaikuttavan sekä välittömästi että välillisesti paitsi organisaatioiden kehittymiseen ja oppimiseen yleensä, erityisesti muutoksen kohtaamiseen työorganisaatioiden johtamisessa.

Larsenin (1994) mukaan eurooppalaisissa yrityksissä koulutuksen ja kehittämisen arvioitiin olevan tärkein painoalue henkilöstövoimavarojen johtamisessa lähitulevaisuudessa. Suomen näkökulmasta tämä tutkimuksen tulos näyttäytyi epäedullisena, sillä aineiston keräysvaiheessa täällä elettiin syvää lamaa eikä henkilöstön kehittäminen näyttänyt kuuluvan painoalueisiin. Sittemmin Suomessakin vuonna 1995 työssä käyvistä palkansaajista jo yli puolet $(52 \%)$ osallistui työantajan resurssoimaan formaaliin henkilöstökoulutukseen (Tilastokeskus 1996), mikä osoittaa kehittämisen ja koulutuksen merkityksen kasvun suomalaisissa yrityksissä vuoden 1991 lamalukemista (41,7\%) (Tilastokeskus 1993). Viimeisimmän teollisuuden selvityksen perusteella henkilöstökoulutuksen volyymin voidaan olettaa olevan kasvussa Suomessa.

Formaali koulutus on kuitenkin vain yksi tapa kehittää henkilöstöä. Osallistuminen $\mathrm{mm}$. erilaisiin projektitehtäviin, tiimityöskentely, neuvottelut ja henkilöstövalinnat edistävät informaalia ja satunnaista oppimista työpaikalla, jonka arvioidaan muodostavan pääosan organisaatioiden henkilöstön kehittämisestä (Marsick \& Watkins 1990, 5-6). 
Siirtyminen formaalista koulutuksesta informaalin ja jatkuvan työssä oppimisen korostamiseen haastaa henkilöstön kehittämisen asiantuntijat jatkuvasti kehittämään myös itseään. Lisäksi se haastaa kehittäjät rakentamaan itselleen organisaatiossa sellaista oppimisen ja muutoksen tukijan roolia, jolla on lisäarvoa sekä organisaatiolle että siellä työskenteleville ihmisille. Ennen perinteinen henkilöstön kehittäjä järjesti koulutusta ja koulutti itse. On arvioitu, että nykyisin kehittäjän työtä määrittävät jatkuva pyrkimys ja tarve tunnistaa muutos- ja oppimishaasteita ja vastata niihin sekä tukea tätä kautta ihmisten kehittymistä ja oppimista sekä kehittämisen yhä vahvempi integroiminen organisaatioiden johtamiseen (Watkins \& Marsick 1992; Brinkerhoff \& Gill 1994, 2238).

\section{Vertailututkimuksen tarkoitus ja toteutus}

Vertailututkimuksen tarkoitus oli arvioida, 1) millaisissa rooleissa henkilöstön kehittäjät työskentelevät, 2) millaisia tuotteita ja palveluita työn tuloksena syntyy sekä 3) millaista osaamista ja tietämistä henkilöstön kehittäjät pitävät tärkeänä omassa työssään. Tutkimuksen tavoitteena oli arvioida McLaganin (1989) henkilöstön kehittäjien työtä kuvaavan mallin validiutta eurooppalaisessa kontekstissa ja saada vertailevaa tutkimusaineistoa, jonka avulla voitaisiin määritellä eurooppalaisten henkilöstön kehittäjien toimintaa muuttuvassa työelämässä ja erityisesti edistää alan kehittymistä ja koulutusta.

Tutkimus toteutettiin postikyselynä. Strukturoitu kyselylomake noudattaa McLaganin (1989) mallia, joka perustuu 1) työroolien, 2) työn tuotosten ja 3) työssä tarvittavien pätevyysalueiden analysointiin. Kyselyn vastaanottaneita henkilöstön kehittäjiä pyydettiin itse arvioimaan työtään kyseisen mallin perusteella.

Kyselylomakkeessa roolilla tarkoitetaan yksilön toimintaa ja käyttäytymistä tietyssä työssä ja henkilökohtaista suhtautumista työhön (Sredl
\& Rothwell 1987, 57-60; Pace, Smith \& Mills 1991, 12-13). Henkilöstön kehittäjän työtä kuvataan lomakkeessa yhdentoista roolin avulla, jotka liittyvät henkilöstökoulutukseen, organisaation kehittämishankkeisiin sekä yksilöiden urasuunnitteluun ja sen tukemiseen. Roolit kuvaavat näin niitä toimintoja, joista henkilöstön kehittämisen kokonaisuutena voidaan sanoa muodostuvan (vrt. Squires 1997). Kehittäjän toiminnassa voi painottua yksi tai useampi työrooli. Vastaajia pyydettiin nimeämään se rooli, jossa he arvioivat käyttävänsä eniten työaikaansa tai joka on heille muulla tavoin merkityksellisin. Lomakkeessa esitettiin 75 mahdollista tuotosta, jotka ovat konkreettisia palveluksia ja tuotteita, joita toiminnan tuloksena syntyy. McLaganin mallissa tuotokset ryhmittyvät roolien mukaisesti. Vastaajia pyydettiin nimeämään työnsä tuotoksia merkityksellisimmän roolin näkökulmasta. Lomakkeessa esitetyt 35 pätevyysaluetta ovat tietämisen ja osaamisen alueita, joiden tärkeyttä työssä ja tuotosten aikaansaamiseksi vastaajat arvioivat. Ne liittyvät henkilöstön kehittämisen suunnitteluun, toteuttamiseen, arviointiin ja johtamiseen sekä vuorovaikutukseen ja tiedon hankintaan ja käyttöön. Myös pätevyysalueet ryhmittyvät roolien mukaisesti. Toisaalta pätevyysalueiden arviointi kertoo pätevyydestä yksilön potentiaalisena ominaisuutena. Toisaalta se kertoo niistä vaatimuksista, joita työ kehittäjiltä käytännössä edellyttää (Ellström 1994, 38-42). Kyselyssä yhdistyvät siten osaamisen ja tietämisen arviointi sekä niiden konteksti eli konkreettisten ammatillisten tehtävien suorittaminen (Hager \& Conczi 1991).

Tutkimuksen kohdejoukkona olivat henkilöstön kehittäjät eli erilaisissa organisaatioissa vaihtelevissa positioissa henkilöstön kehittämisen suunnittelusta, toteutuksesta ja arvioinnista vastaavat asiantuntijat. He vastaavat pääsääntöisesti henkilöstön kehittämisestä päätoimisesti tai osa-aikaisesti organisaation sisällä, mutta voivat olla mukana kehittämishankkeissa organisationaaliselta positioltaan ulkoisina, yksityisinä kouluttajina tai konsultteina tai koulutusyrityksen palveluksessa (Nadler \& Nadler 1991, 136-139). 
Kehittäjät ovat varsin vaikeasti määriteltävissä yhtenäisten työ- tai virkanimikkeiden ja koulutustaustan puuttumisen takia. Tutkittavien saavutettavuuden varmistamiseksi tutkittavat valittiin pääsääntöisesti eri maissa henkilöstönkehittämis- ja henkilöstökoulutusalan järjestöistä, joiden jäsenistön oletettiin edustavan kohdejoukkoa. Alkuvaiheessa Belgiassa, Englannissa, Pohjois-Irlannissa ja Italiassa tutkittavien valinnan ja kyselyn suoritti alan järjestöstä valittu yhteyshenkilö. Hollannissa, Saksassa ja Suomessa tutkittavat päätettiin valita suoraan yhdestä tai kahdesta alan järjestöstä ja varmistaa näin niiden tuki kyselylle. Tutkittaviksi valittiin mahdollisimman suuri osa jäsenistöstä, koska kyselyllä haluttiin tavoittaa laaja potentiaalisten vastaajien joukko.

\section{Tutkimusaineisto ja sen analysointi}

Taulukko 1 kuvaa maittain tutkittavien määrän, vastausprosentin ja kyselyn ajankohdan. Taulukosta käy myös ilmi kansainvälisten kyselytutkimusten perusongelma eli tutkimusjoukon kato aineistonkeräysvaiheessa, vaikka kyselylomakkeiden esitestauksella, järjestöjen taustatuella ja kyselylomakkeiden palauttamiseen aktivoivilla toimenpiteillä pyrittiin estämään katoa (vrt. esim. Brewster \& Hegewish 1994). Hollannin korkeaa vastausprosenttia selittänee tutkimuksen kaksivaiheisuus. Ensimmäisessä, potentiaalisia vastaajia jäljittävässä kyselyssä $(\mathrm{N}=1176)$ vastausprosentti oli 36 prosenttia ja tälle ryhmälle $(n=425)$ lähetettiin varsinainen kysely. Vastanneiden ja vastaamatta jättäneiden eroja ikä- ja sukupuolijakaumissa oli mahdollista vertailla Hollannin, Saksan ja

\section{Taulukko 1. Tutkimusaineisto eri maista}

\begin{tabular}{|c|c|c|c|c|c|}
\hline Belgia & $\begin{array}{l}\text { lähetetyt } \\
200\end{array}$ & kyselyt & $\begin{array}{l}\text { palautetut } \\
53\end{array}$ & $\begin{array}{l}\text { vastausprosentti } \\
26.5\end{array}$ & $\begin{array}{l}\text { ajankobta } \\
1993\end{array}$ \\
\hline Englanti & 1740 & & 228 & 13.1 & 1993 \\
\hline Pohjois-Irlanti & 330 & & 37 & 11.2 & 1993 \\
\hline Italia & 700 & & 105 & 15.0 & 1993 \\
\hline Hollanti & 425 & & 297 & 70.0 & 1993 \\
\hline Saksa & 998 & & 190 & 19.0 & 1995-1996 \\
\hline Suomi & 699 & & 164 & 23.5 & 1995-1996 \\
\hline
\end{tabular}

Suomen osalta. Vertailu osoitti, että merkittäviä poikkeamia näiden ryhmien välillä ei ollut. Tässä artikkelissa kuvataan ja vertaillaan Englannin, Italian, Hollannin, Saksan ja Suomen tuloksia.

Vastaajien voidaan olettaa edustavan henkilöstön kehittämistehtävissä toimivia asiantuntijoita. Vuoden 1993 kyselyissä kaikki vastaajat, Saksassa noin 70 prosenttia ja Suomessa noin 60 prosenttia käyttivät puolet tai enemmän työajastaan henkilöstön kehittämistehtävissä. Vastaajista 59-72 prosenttia edusti sisäisiä kehittäjiä, jotka toimivat omissa työskentelyorganisaatioissaan henkilöstön kehittämisestä vastaavissa tehtävissä ja 41-28 prosenttia katsoi toimivansa ulkoisina, joko itsenäisinä kouluttajina ja konsultteina tai koulutus- ja kehittämispalveluja muille tarjoavien organisaatioiden palveluksessa. Saksassa enemmistö vastajista kuitenkin oli ulkoisia kehittäjiä (56\%). Useimmiten vastaajat työskentelivät koulutus-/henkilöstön kehittämispäällikkönä tai kouluttajana/ konsulttina. Kysely osoitti, että henkilöstön kehittäjillä on useita erilaisia tehtävänimikkeitä ja vaihtelevat tehtävät. On huomioitava, että järjestöjen edustajina tutkittavat ovat valikoituneita henkilöitä, jotka ovat kiinnostuneita oman alansa kehittämisestä ja orientoituneet henkilöstön kehittämisuralle, mikä tässä tutkimuksessa voi olla etu tavoitteiden kannalta.

Suomessa vastaajien sukupuolijakauma oli tasainen (miehiä 53, naisia 47 prosenttia), muissa maissa kyselyyn vastanneista kehittäjistä selvä enemmistö oli miehiä. Miehet olivat keskimäärin 35-54 -vuotiaita, kun taas naiset olivat hieman nuorempia eli 25-44 -vuotiaita. Kehittäjien koulutustaso oli korkea joka maas- 
sa. Korkea- tai yliopistoasteen koulutuksen saaneiden määrä vaihteli Saksan 65 prosentista Suomen 90 prosenttiin. Tietoa kehittäjien peruskoulutusalasta ei kaikista maista ole saatavissa, mutta erityistä ja erimuotoista pätevöitymistä henkilöstön kehittämisen alalla he olivat hankkineet. Eniten lisäkoulutusta oli hollantilaisilla $(93 \%)$ ja suomalaisilla $(80 \%)$, muilla hieman harvemmin: Englanti (54\%), Italia $(38 \%)$ ja Saksa $(48 \%)$.

\section{Tulokset}

\section{Roolit: muutosagentteja, kouluttajia, suunnittelijoita ja johtajia}

Kuviosta 1 näkyy kehittäjien yleisimmin käyttämät roolit oman työnsä painoalueen kuvaamisessa. Organisaation muutosagentin, kouluttajan, henkilöstön kehittämispäällikön ja suunnittelijan roolit näyttävät selvimmin määrittävän henkilöstön kehittäjän työtä. Muutosagenttius korostuu Suomessa ja Englannissa, kun taas Italiassa suunnittelija ja kouluttaja ja Saksassa erityisesti kouluttaja ovat ensisijaisia rooleja. Hollannissa työlle tyypillisen toimin- nan kuvaus roolien mukaan jakautuu tasaisesti. Urasuunnittelunohjaajan ja tarpeiden tunnistajan roolit tulevat selvimmin esille hollantilaisilla kehittäjillä, kun muissa maissa ne luonnehtivat kehittäjän toimintaa varsin vähän. Vähiten tai ei ollenkaan työn painoalueen kuvauksessa käytettiin kuvion ulkopuolelle jääneitä arvioijan, tutkijan, markkinoijan ja HRDmateriaalien kehittäjän rooleja.

Suomessa ja Saksassa tehdyissä kyselyissä vastaajille annettiin mahdollisuus kuvata toimintaansa myös muilla kuin McLaganin (1989) mallin rooleilla. Siten sekä Saksassa että Suomessa vastaajista noin kolmasosa nimesi työtään kuvaavia lisärooleja. Vastausten perusteella suomalaisesta aineistosta tunnistettiin kolme roolia, jotka sisälsivät erilaisia elementtejä verrattuna mallin rooleihin. Nämä nimettiin valmentajan, reflektiivisen kehittäjän ja konsultoivan yhteyksientekijän rooleiksi. Valmentajan roolissa korostuivat selkeästi yksilöiden ja työryhmien valmentaminen, rohkaiseminen ja tukeminen kehittämishankkeiden eri vaiheissa. Reflektiivisenä kehittäjänä toimimisessa korostuivat reflektiivisen ajattelun ja oppimistaitojen tukeminen yksilö-, ryhmä- ja organisaatiota-

\section{Kuvio 1. Kehittäjien tyypillisimmät roolit maittain}

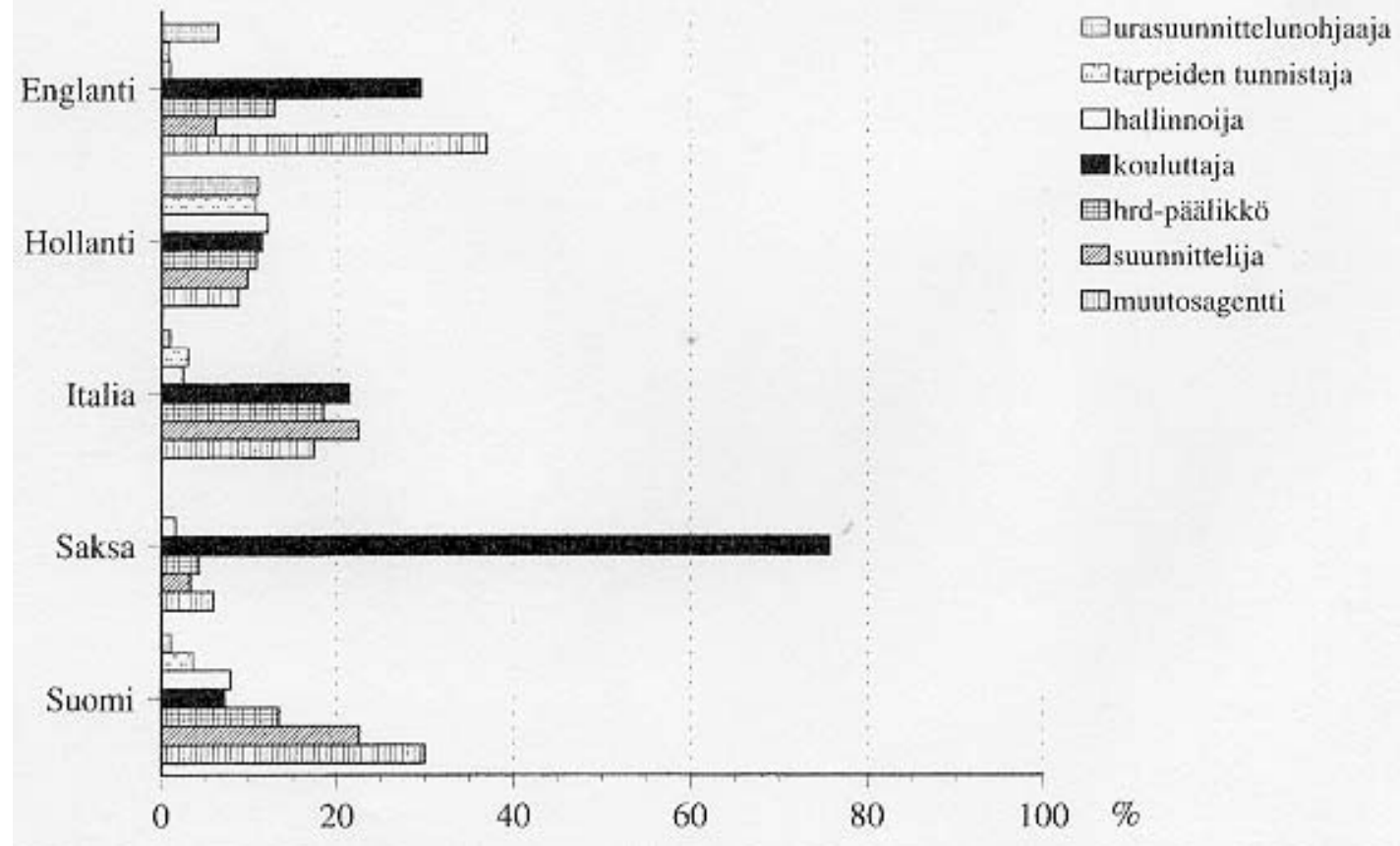


soilla. Työntekijöiden ja johdon intressien yhteensovittaminen sekä henkilöstön kehittämisen ja organisaation liiketoimintatavoitteiden integroiminen olivat tyypillisiä konsultoivalle yhteyksientekijälle. Myös Saksassa nousi esille kehittäjän rooli, jota voidaan kutsua valmentajaksi. Toinen saksalaisessa aineistossa erottunut rooli painotti erityisesti yrittäjyyttä ja liiketoiminnan "pyörittämistä" kehittäjän työssä. Nämä sisällöltään uudet roolit olivat kuitenkin erittäin harvoin niitä, jotka olisivat vieneet eniten kehittäjän työaikaa ja siten luonnehtineet koko työtä.

\section{Tuotokset: suunnitelmia, strategioita, ohjausta ja tukea}

Kehittäjien työn yleisimmät tuotokset painottuivat (taulukko 2) henkilöstön kehittämisen ja organisaation muutoshankkeiden suunnitteluun ja suunnitelmien integroimiseen organisaation muuhun toimintaan sekä tiimien ja ryhmien työskentelyn tukemiseen. Ne viestivät henkilöstön kehittämisen olevan organisaatiossa yksilöihin ja ryhmiin kohdistuvaa toimintaa, jonka täytyy osoittaa tarpeellisuutensa esimerkiksi si-

\section{Taulukko 2. Yleisimmät työn tuotokset henkilöstön kehittäjän työssä maittain}

ENGLANTI $(\mathrm{n}=105)$

Erilaisten kehittämis- tai muutosmallien tai teorioiden esittäminen ja soveltaminen 75,1

Stategiat yksilö- ja organisaatiokäyttäytymisen analysointiin $\quad 73,3$

$\begin{array}{ll}\text { Ryhmäkeskustelujen ohjaus } & 73,3\end{array}$

HRD-menetelmien/-mahdollisuuksien esittely organisaatiossa 71,2

$\begin{array}{ll}\text { Muutokset organisaation ryhmänormeissa, arvoissa ja kulttuurissa } & 69,9\end{array}$

HOLLANTI ( $\mathrm{n}=297)$

Henkilöstön tukihenkilönä toimiminen, ammatillinen ohjaus $\quad 77,8$

HRD-toiminnan tuotteiden ja palvelujen myönteisen imagon luominen org:ssa 75,8

Arviointiprosessit $\quad 75,4$

Arviointitulokset, johtopäätökset ja suositukset $\quad 74,7$

$\begin{array}{ll}\text { Palaute henkilöstölle oppimisesta } & 73,7\end{array}$

ITALIA $(\mathrm{n}=80)$

$\begin{array}{ll}\text { Erilaisten HRD-hankkeiden suunnitelmat } & 72,5\end{array}$

$\begin{array}{ll}\text { HRD-yksikön strategia } & 67,5\end{array}$

Henkilöstön kehittämisen pitkän tähtäimen suunnitelmat $\quad 65,0$

Suositukset organisaation johdolle koskien henkilöstön kehittämistä $\quad 51,3$

SAKSA $(n=190)$

Henkilöstön toiminnan/käyttäytymisen muutos ohjauksen/neuvonnan tuloksena 88,9

HRD-menetelmien/-mahdollisuuksien esittely organisaatiossa $\quad 87,4$

$\begin{array}{ll}\text { Palaute henkilöstölle oppimisesta } & 82,1\end{array}$

$\begin{array}{ll}\text { Ryhmäkeskustelujen ohjaus } & 82,1\end{array}$

$\begin{array}{ll}\text { Ohjatut oppimistilanteet } & 77,4\end{array}$

SUOMI ( $\mathrm{n}=164)$

Suosituksen organisaation johdolle koskien henkilöstön kehittämistä $\quad 78,7$

$\begin{array}{ll}\text { Muutoshankkeiden suunnittelu } & 75,6\end{array}$

$\begin{array}{ll}\text { Tiimityöskentelyn tukeminen } & 75,6\end{array}$

Erilaisten kehittämis- tai muutosmallien tai teorioiden esittäminen ja soveltaminen 74,4

$\begin{array}{ll}\text { Sisäisten ja ulkoisten asiakassuhteiden hoito } & 74,4\end{array}$ 
säisen markkinoinnin keinoin. Suomessa tyypillisiä tuotoksia olivat henkilöstön kehittämisen suunnittelu ja integrointi organisaation muutoshankkeisiin, kun taas Hollannissa, Englannissa ja Saksassa on havaittavissa yksilöiden, ryhmien ja organisaation oppimiseen, ohjaukseen ja arviointiin liittyviä tuotoksia. Italiassa tuotokset liittyivät henkilöstön kehittämistoiminnan johtamiseen ja hankkeiden suunnitteluun. Tulokset Saksasta, Suomesta ja Hollannista kertovat, että tuotokset, jotka liittyvät selkeästi käytännön järjestelyihin, kuten välineiden ja laitteistojen hankintaan ja käyttösuunnitelmiin, ovat vain harvoin kehittäjän työn tuotoksia.

Yleisimmät tuotokset heijastavat myös useimmiten tyypillisimmäksi arvioitua roolia kussa- kin maassa. Esimerkiksi suomalaisten kehittäjien keskuudessa yleisimmät tuotokset kuuluvat McLaganin (1989) mallin mukaan organisaation muutosagentin rooliin, kun taas Saksassa korostuvat opettajan/kouluttajan toimintaan liittyvät tuotokset. Italialaisten kehittäjien yleisimmät tuotokset kuuluvat suunnittelijan tai HRD-päällikön toimintaan. Englannin ja Hollannin osalta yleisimmissä tuotoksissa on enemmän hajontaa lähinnä kouluttajan, arvioijan, tutkijan, tarpeiden tunnistajan, urasuunnittelun ohjaajan ja markkinoijan rooleihin.

\section{Pätevyysalueet: vuorovaikutus- ja organisaatio-osaamista}

Kehittäjät arvioivat työnsä kannalta useimmiten erittäin tärkeäksi pätevyysalueita, jotka liit-

\section{Taulukko 3. Useimmiten tärkeimmiksi arvioidut pätevyysalueet henkilöstön kehittäjän työs-} sä maittain

Pätevyysalueet

ENGLANTI $(\mathrm{n}=205)^{1}$

Palautteen antamisen taito

Suhdetoimintataidot

Ryhmäprosessointitaidot

Itsetuntemus

Organisaatiokäyttäytymisen

ymmärtäminen

HOLLANTI $(\mathrm{n}=297)$

Selkeiden ja kuvaavien tavoitteiden suunnittelutaito

Suhdetoimintataidot

Palautteen antamisen taito

Intellektuaalinen joustavuus

Tilanteiden observointitaito

ITALIA $(\mathrm{n}=80)^{2}$

Intellektuaalinen joustavuus erittäin tärkeä

$\%$

$$
\begin{aligned}
& 79,5 \\
& 75,7 \\
& 72,4 \\
& 71,9 \\
& 69,5
\end{aligned}
$$

Toimintaorganissaation tunteminen

Suhdetoimintataidot

Sisällöllinen perehtyneisyys
71,4

70,0

66,7

66,0

65,7

80,2

66,7

63,0

54,3

1 1992-1993 arvioidut tärkeimmät pätevyysalueet seuraavien 3-5 vuoden aikana

2 1992-1993 arvioidut tärkeimmät pätevyysalueet seuraavien 3-5 vuoden aikana. Tähän on saatu vain neljä tärkeintä pätevyysaluetta. 
tyvät vuorovaikutus- ja kommunikointitilanteisiin sekä tiedonhankintaan ja -käyttöön, ks. taulukko 3). Yksittäisistä pätevyysalueista taito antaa palautetta, Italiaa lukuun ottamatta, kuului erittäin tärkeäksi arvioituun osaamiseen. Samoin suhdetoimintataidot arvioitiin tärkeiksi Englannissa, Hollannissa ja Italiassa. Saksalaisten ja suomalaisten kehittäjien mielestä osa erittäin tärkeätä osaamista oli ymmärtää aikuisen oppimista. Saksassa arvostettuun osaamiseen kuului myös ohjaus- ja valmennustaito, Suomessa visiointikyky. Toisaalta myös organisaation johtamiseen liittyvän pätevyyden tärkeys tuli esille toimintaorganisaation tuntemisena Suomessa ja Italiassa. Useimmiten erittäin tärkeiksi arvioitiin yhteensä 16 erilaista pätevyysaluetta, mikä osoittaa osaamisen monialaisuuden. Vain harvoin erittäin tärkeiksi arvioituja pätevyysalueita Saksassa, Suomessa ja Hollannissa olivat tietokoneen ja muun tietoteknologian käyttöön sekä tutkimukseen liittyvät taidot. Lisäksi vain runsas 10 prosenttia vastaajista sekä Suomessa että Saksassa arvioi urasuunnittelun ohjaukseen liittyvän osaamisen erittäin tärkeäksi.

Suomessa, missä korostui organisaation muutosagentin rooli, myös tärkeimmiksi arvioidut pätevyysalueet liittyivät muutoksen tukemisessa tarvittavaan organisaatiotuntemukseen, tiedonkäsittely ja -analysointitaitoihin sekä vuorovaikutusosaamiseen. Sama on havaittavissa myös Englannin, Hollannin ja Italian tuloksissa. Saksassa korostuivat kouluttajalle ominaiset tiedot ja taidot ohjauksessa, arvioinnissa ja palautteenantamisessa.

\section{Pohdinta}

Tulokset osoittavat, että eurooppalaisten henkilöstön kehittäjien rooleissa ilmenee toisaalta henkilöstön kehittämisen monialaisuus, toisaalta kulttuurisidonnaisuus. Kehittäjänkään työtä ei voida yksiselitteisesti kuvata yhdellä roolilla, vaikka tiettyjä painoalueita onkin havaittavissa. Näyttääkin siltä, että esimerkiksi Suomessa ja Englannissa kehittäjien käsitykset työstään ja roolistaan organisaatiossa heijastavat yleisiä työelämän muutoksia. Työn painopisteen voidaan arvioida olevan enemmän muutoksen edistämisessä ja organisaatioiden kehittämiseen pyrkivän muutosagentin roolissa kuin perinteisessä kouluttajan roolissa. Erityisesti Suomessa tämä tulos vaikuttaa luonnolliselta suhteessa kuluvan vuosikymmenen työelämän rajuihin muutoksiin, jotka ovat edellyttäneet organisaatioilta ja edelleen henkilöstön kehittäjiltä oman toiminnan uudelleenarviointia, varsinkin julkisella sektorilla (vrt. Filander 1997). Vastaava ilmiö näkynee myös Englannin tuloksissa, toisaalta siellä kyselyn ajankohtana henkilöstön kehittämisen strategista roolia organisaation kehittämisessä ja oppivaa organisaatiota korostavat trendit olivat juuri vahvasti esillä (ks. esim. Megginson, Joy-Matthews \& Banfield 1993).

Saksassa taas kouluttajan roolin korostuminen organisationaaliselta positioltaan sisäistenkin kehittäjien keskuudessa voi johtua toisaalta perinteisestä koulutusajattelusta, toisaalta koulutusjärjestelmästä, joka korostaa yrityksissä annettavan koulutuksen tärkeää roolia ammatillisessa koulutuksessa. Erot eri maiden välillä osoittavat, että globaalit esimerkiksi jatkuvaa muutosta tai oppivaa organisaatiota korostavat trendit eivät aina välttämättä vaikuta henkilöstön kehittämiseen ja kehittäjän roolin määrittymiseen niin paljon kuin esimerkiksi kansallinen talous- ja koulutuspolitiikka tai teollisuuden kehitystrendit (Hansen \& Brooks 1994).

Toisaalta eroja voi selittää itse aineisto. Vaikka tulosten perusteella vastaajat näyttävät edustavan henkilöstön kehittämistyössä työskenteleviä, käytettyjen järjestöjen toiminnassa voi olla painotuseroja, jotka vaikuttavat jäsenistön valikoitumiseen ja edelleen tuloksiin. Hollannissa aineiston koko ja alkukysely ovat voineet edesauttaa roolien tasaista jakautumista. Lisäksi, koska kyse oli niin vaikeasti määriteltävissä olevasta asiantuntijajoukosta, tutkimuksen kartoittava ja yleistävä pyrkimys muodostui tutkittavien tavoitettavuudessa ongelmalliseksi. Tulosten yleistettävyyttä tuleekin tarkastella lähinnä suhteessa järjestöjen jäsenistöön. 
Koska roolia arvioidaan subjektiivisena työotteena, voidaan organisationaalisten ja henkilökohtaisten tekijöiden olettaa olevan yhteydessä roolin muotoutumiseen ja selittävän hajontaa eri roolien kesken. Tätä vahvisti näiden tekijöiden välisten yhteyksien tarkastelu suomalaisessa tutkimusasetelmassa. Tarkastelu osoitti, että Suomessa kehittäjien koulutusala, organisationaalinen positio, työn sisältö sekä organisaation toimintasektori ovat tilastollisesti merkitsevästi yhteydessä siihen, millaiseksi oma rooli arvioidaan. Esimerkiksi sisäiset päätoimiset kehittäjät arvioivat toimivansa useimmiten suunnittelijoina tai henkilöstön kehittämisen johtotehtävissä, kun taas sisäiset osa-aikaiset kehittäjät näkivät itsensä useimmiten muutosagenttina (Valkeavaara 1997).

Suomessa ja Saksassa esille nousseet uudenlaiset elementit, jotka rikastuttavat henkilöstön kehittäjän työn ja roolien kuvausta suhteessa McLaganin (1989) malliin, heijastavat myös kehittäjän roolin muuttumista ja viittaavat mallin uudelleen arviointiin. Erityisesti valmentajuudella, konsultatiivisella otteella ja reflektiivisen ajattelun tukemisella on yhtymäkohtia McLaganin (1996) myöhemmin esittämään uuteen arvioon henkilöstön kehittäjän rooleista. Näiden roolien, joskin vähäinen, esiintyminen tukee havaintoja kehittäjän konsultatiivisen roolin vahvistumisesta (Tjepkema \& Wognum 1996) ja voi yleisestikin ilmentää organisaatioiden pyrkimyksiä oppiviksi organisaatioiksi tai ainakin orientoitumista oppimista tukeviksi (Gephart, Marsick, van Buren \& Spiro 1996). Tuloksissa on myös nähtävissä henkilöstön kehittäjien oma pyrkimys arvioida toimintaansa uudelleen ja vastata uusiin haasteisiin, joita työelämä asettaa organisaatioiden tukemalle koulutukselle ja oppimiselle. Jos muutos nähdään oppimistilanteena, esimerkiksi Suomessa tämän muutoksen tukeminen näytti olevan yksi keskeinen ulottuvuus kehittäjän työssä. Toisaalta urasuunnittelunohjaajan ja tarpeiden tunnistajan roolit, jotka voivat olla olennaisia oppimista tukevissa organisaatioissa, tulivat selkeästi esille vain Hollannissa ja vähäisesti ajankohdaltaan myöhemmin tehdyissä Saksan ja Suomen kyselyissä. Myöskään ura- suunnitteluun liittyvä osaaminen ei saanut suurta painoarvoa. Voidaan arvioida, että vaikka tulokset antavat viitteitä kehittäjille ehdotetuista tukijan, huolehtijan ja valmentajan rooleista postmoderneissa oppimisverkostoissa (Juuti 1997), nämä roolit ovat vasta tulossa osaksi tätä päivää. Tätä kehityssuuntaa tukevat myös yleisimmät työn tuotokset, joita voi kuvata lähinnä tieto- ja tukipalveluiksi, joiden avulla tilanteita analysoidaan ja ohjataan edelleen.

Henkilöstön kehittäjän tärkeimmästä pätevyydestä näyttää roolien erilaisuudesta huolimatta löytyvän yhteinen ydin: vuorovaikutukseen ja tiedon hankintaan ja käyttöön sekä organisaatioiden toimintaan liittyvä osaaminen ja tietäminen. Tulokset kertovat toiminnallisesta ja informaalista osaamisesta, joka on tärkeää avoimissa ja vaikeasti määriteltävissä kehittämistilanteissa toimiville asiantuntijoille. Lisäksi tulokset osoittavat henkilöstön kehittämisen monitieteisyyden sekä aseman asiantuntijuusalueena, jossa korostuvat intuitio, itsearviointi sekä toiminnallinen tieto liittyen erityisesti ihmisten väliseen vuorovaikutukseen. Tämä tukee työelämän aikuiskoulutuksen oppimisajattelua, joka pyrkii vastaamaan työelämän vaatimuksiin korostamalla tiedon jakamisen ja valistamisen asemesta tiedon ja osaamisen rakentamista vuorovaikutusprosessissa organisaatiossa. Taidot tietokoneen ja tietoteknologian käytössä arvioitiin harvoin erittäin tärkeiksi, mitä voi selittää kehittäjän työn luonne tai näiden välineiden käytön itsestäänselvyys tämän päivän työelämässä. Lisäksi työelämän vaatimukset heijastuvat kehittäjien arvioinneissa pätevyysalueista ainakin sillä perusteella, että suomalaisten ja englantilaisten mielestä McLaganin mallin mukaiset muutosagenttina toimimiseen liittyvät pätevyydet kuuluivat tärkeimpiin kun taas saksalaiset korostivat opetus- ja ohjauspätevyyttä. Henkilöstön kehittäjien ammatillista kehittymistä ajatellen osaaminen ja tietäminen liittyen yksilöiden ja organisaatioiden ongelmien ja tarpeiden tunnistamiseen, analysointiin ja ratkaisumahdollisuuksien etsimiseen organisaatioympäristöissä näyttää painottuvan teknis-rationaalisesti määrittyviä tieto- tai taitoalueita enemmän. 
Vertailututkimuksen tulokset valottavat henkilöstön kehittäjän työn nykytilaa eurooppalaisessa raameissa sekä maakohtaisia ominaispiirteitä, mikä antaa eväitä esimerkiksi alan koulutuksen suunnitteluun. McLaganin 1980-luvun lopulla kehittämän mallin mukaisesti voidaan edelleen kuvata henkilöstön kehittäjän tyypillisiä työrooleja ja niihin liittyviä tuotoksia ja pätevyyttä, vaikkakin tulokset eri maissa vahvistivat vain osittain mallin rooli-tuotos- tai rooli-pätevyysalue-profiileja. Mielenkiintoista on, että malli perustuu USA:ssa tehtyihin laajoihin eksperttihaastatteluihin ja kyselyihin, joissa kehittäjiä pyydettiin arvioimaan työnsä tulevaisuusnäkymiä. Siten näiden eurooppalaisten tulosten valossa henkilöstön kehittämisen tulevaisuuden trendejä pystyttiin 1980-luvun lopulla arvioimaan vähintäänkin tyydyttävästi. Lisäksi tämän vertailun mukaan tulevaisuusorientaatio pätevyyksien arvioinnissa Italiassa ja Englannissa tuotti samansuuntaisia tuloksia kuin nykytilanteen kartoitus muissa maissa myöhempänä ajankohtana. Toisaalta juuri amerikkalainen roolilähtöisyys on voinut tuntua vaikealta oman työn arvioinnissa ja kuvaamisessa ja siten selittää kyselyn heikkoja vastausprosentteja eri maissa.

Voidaan todeta, että tulokset kertovat henkilöstön kehittäjien eksplisiittisistä työkäytännöistä, mutta viestivät myös kehittämistyössä tarvittavan ja käytettävän asiantuntijuuden ja sen jatkuvan kehittymisen prosessilähtöisen tarkastelun tarpeesta. Tätä osoittaa esimerkiksi se, että kun kehittäjille annettiin mahdollisuus arvioida toimintaansa yli mallin antamien raamien, se tuotti uutta tietoa työrooleista. Asiantuntijoina henkilöstön kehittäjät edustavat vaikeasti määriteltävissä ongelmatilanteissa tarvittavaa laaja-alaista ja kehittyvää osaamista, jonka asema asiantuntijuustutkimuksen painoalueena on vahvistunut. Tämä tutkimus onkin antanut lähtökohdan jatkotutkimukselle, joka kohdistuu henkilöstön kehittäjien asiantuntijuuteen ja sen kehittymiseen muuttuvan työelämän oppimisverkostoissa.

\section{Iähteet}

ARNOLD, R. \& MULLER, H-J. (1992) Berufsrollen betrieblicher weiterbildner. Fachbeiträge 21 (5), 36-41.

BREWSTER, C. \& HEGEWICH, A. (toim.) (1994) Policy and practice in European buman resource management. London: Routledge.

BRINKERHOFF, R. O. \& GILL, S. J. (1994) The learning alliance. Systems thinking in buman resource development. San Francisco: JosseyBass.

CHALOFSKY, N. (1992) A unifying definition for the human resource development profession. Human Resource Development Quarterly 3 (2), 173-182.

ELLSTRÖM, P-E. (1994) Kompetens, utbildning och lärände $i$ arbetslivet. Stockholm: Gotab.

Eurotechnet (1995) Human resource development and training strategies: the experience and results of the Eurotechnet programme:four priority fields of focus. European Commission. Luxembourg: Office for Official Publications of the European Communities.

FILANDER, K. (1997) Kehittäjät tulevaisuuden verkostoasiantuntijoina. Teoksessa Kirjonen, J., Remes, P. \& Eteläpelto, A. (toim.) Munttuva asiantuntijuus (ss. 136-148). Jyväskylä: Jyväskylän yliopistopaino.

GEPHART, M. A., MARSICK, V. J., van BUREN, M. E. \& SPIRO, M. S. (1996) Learning organizations come alive. Training and Development 50 (12), 34-45.

GINKEL, K. van, Mulder, M., \& Nijhof, W. (1994a, June) Role profiles of HRD practitioners in the Netherlands. Paper presented at the IRNED conference, Milan.

GINKEL, K. van, MULDER, M. \& NIJHOF, W. (1994b) HRD-profielen in Nederland. Appendices.

Enschede: Universiteit Twente, Faculteit der Toegepaste Onderwijskunde, Vakgroep Curriculumtechnologie.

HAGER, P. \& CONZI, A. (1991) Competencybased standards: a boon for continuing professional education? Studies in Continuing Education 13 (1), 24-40.

HANSEN, C. D. \& BROOKS, A. K. (1994) A review of cross-cultural research on human resource development. Human Resource Development Quarterly 5 (1), 55-74.

HANSEN, C. D., KAHNWEILER, W. M. \& 
WILENSKI, A.S. (1994) Human resource development as an occupational culture through organizational stories. Human Resource Development Quarterly 5 (3), 253-267.

JUUTI, P. (1997) Kulkuri ja peluri oppijoina. Aikuiskasvatus 17 (1), 4-11.

LARSEN, H. H. (1994) Key issues in training and development. Teoksessa Brewster, C. \& Hegewish, A. (toim.) Policy and practice in European buman resource management (ss. 107 - 121). London: Routledge.

LAUNOS, E. \& PEISA, S. (1979) Valtion henkilöstökouluttajien ammattikuvatutkimus. Valtion koulutuskeskus. Julkaisusarja B 6. Helsinki: Valtion painatuskeskus.

MARSICK, V. J. (1988) A new era in staff development. Teoksessa Marsick, V. J. (Toim.) Enhancing staff development in diverse settings. New directions for Continuing Education, 38. (ss. 9-21). San Francisco: JosseyBass.

MARSICK, V. J. \& WATKINS, K. (1990) Informal and incidental learning in the workplace. London: Routledge.

McLAGAN, P. (1989) Models for HRD practice. Training and Development Journal 43 (9), 49. 59.

McLAGAN, P. (1996) Great ideas revisited. Training and Development Journal 50 (1), 60-65.

McLAGAN, P. \& BEDRICK, D. (1983) Models for excellence: The results of the ASTD training and development competency study. Training and Development Journal 37 (6), 10-20.

MEGGISON, D., JOY-MATTHEWS, J. \& BANFIELD, P. (1993) Human resource development. London: Kogan Page.

NADLER, L. \& NADLER, Z. (1991) Developing buman resources (2nd printing.). San Francisco: Jossey-Bass.

PACE, R. W., SMITH, P. C. \& MILLS, G. E. (1991) Human Resource Development, the field. New Jersey: Prentice-Hall.

ODENTHAL, L. \& NIJHOF, W. (1996) HRD roles in Germany. Studies in Human Resource Development 13. University of Twente, Enschede. De Lier: Academish Boeken Centrum.

PINTO, P. \& WALKER, J. (1978) What do training and development professionals really do? Training and Development Journal 32 (7), 58 64.

RIJK, R. N. de, MUlder, M., \& NiJHOF, W. (1994) The HRD profession in the '90s. Table report of a survey on the HRD profession in four European countries. Enschede: University of Twente, Faculty of Educational Science and Technology, Division of Curriculum Studies.

SQUIRES, G. (1997) Evaluating teaching and improving learning. Lifelong Learning in Europe 2 (2) 86-91.

SREDL, H. \& ROTHWELL, W. (1987) The ASTD reference guide to professional training roles \& competencies Vol. 1. Amherst: HRD press.

Tilastokeskus (1993) Koulutus 1993. Koulutus 1993:7. Helsinki. Tilastokeskus.

Tilastokeskus (1996) Aikuiskoulutustutkimus 1995, ennakkotietoja. Koulutus 1996:6. Helsinki: Tilastokeskus.

TJEPKEMA, S. \& WOGNUM, I. (1996, May) From trainer to consultant? Paper presented at the ECLO conference, Copenhagen.

VAHERVA, T. \& VALKEAVAARA, T. (1997) Henkilöstön kehittäjän rooli oppivassa organisaatiossa. Teoksessa Sallila, P. \& Tuomisto, J. (toim.) Työn muntos ja oppiminen. Aikuiskasvatuksen 38. Vuosikirja. (ss.197-221) Helsinki: BTJ Kirjastopalvelu Oy.

VALKEAVAARA, T. (1997) HRD practitioners analysing their work: what does it tell about their present role in working life? Teoksessa Remes, P., Tosse, S., Falkenkrone, P. \& Bergstedt, B. (toim.). Social change and adult education research. Adult education research in Nordic Countries 1996. (ss. 14-40) Jyväskylä: Jyväskylän yliopistopaino.

WATKINS, K., \& MARSICK, V. (1992) Building the learning organization: a new role for humanresource developers. Studies in Continuing Education 14 (2), 115-129.

Artikkeli saapui 25.5. 1997. Se hyväksyttiin julkaistavaksi toimituskunnan kokouksessa 22.8.1997. 